\title{
Analysis of climate variables and strategies for adapting agriculture to climate change in the Northern Trans-Urals
}

\author{
Sergei Petrov ${ }^{1, *}$, Natali Mamaeva ${ }^{1,2}$, and Maksim Narushko ${ }^{1}$ \\ ${ }^{1}$ Tyumen Scientific Center SB RAS, Malygina str. 86, 625026, Tyumen, Russia \\ ${ }^{2}$ Industrial University of Tyumen, Volodarskogo str. 38, 625000, Tyumen, Russia
}

\begin{abstract}
Today, humanity is faced with the problem of a changing planetary climate. At the same time, there is no common point of view on the main causes and trends of the dynamics of the modern climate, its consequences for individual components of the natural environment, as well as on the optimization of land use in Siberia. The paper examines the influence of the relative humidity of the air on the yield and gross harvest of grain and leguminous crops. It was revealed that the climate becomes more favorable for the cultivation of grain and leguminous crops in the Northern Trans-Urals, thus, from the zone of risky farming, the region can move to a more favorable area for active economic use of the agricultural landscape. This dictates the need to take measures aimed at adapting agriculture to new conditions and focused on environmentally friendly land use technologies.
\end{abstract}

\section{Introduction}

Today humanity is faced with the problem of a changing planetary climate [1]. It can be considered an established fact of the temporal dynamics of the Earth's climate, occurring in individual regions at different scales and intensity [2]. The problem of a changing climate requires close attention of various specialists, as well as a comprehensive study of climatic characteristics, such as ambient temperature, air humidity, etc. Thus, the global atmosphere contains about $1 \%$ water vapor by volume. Its distribution over the globe is very uneven and depends significantly on air temperature [3]. According to Roshydromet estimates, climate warming in Russia is about 2.5 times more intense than the average for the globe [4]. At the same time, the five-year period 2011-2015 was the warmest. В 2016 г. отмечено дальнейшее повышение средней годовой глобальной приземной температуры воздуха. According to forecasts, in northern latitudes, the temperature increase will continue until the end of the 21 st century [5]. Global warming resulting from an increase in the concentration of greenhouse gases will lead to an increase in humidity in the atmosphere, which is a very important environmental parameter, since water vapor itself is a greenhouse gas, therefore, this process will be associated with an additional increase in temperature. Water vapor is a significant contributor to the greenhouse effect

* Corresponding author: tumiki@yandex.ru 
with strong positive feedback [3]. Water vapor is one of the most important variables that determine the Earth's energy balance and hydrological cycle. It is also an important component of the water cycle because water vapor is the main source of water for precipitation in all weather systems [6]. Water vapor, along with the ability to absorb radiation in almost the entire infrared range, is also a source of $\mathrm{OH}$ radicals, which are extremely active oxidants and to a large extent (despite very low concentrations $(\sim 105-107$ $(1 / \mathrm{cm} 3)))$ determine the chemical composition of the troposphere [3]. At the same time, the most pronounced warming is observed in the winter period of time, which largely determines the success of overwintering agricultural crops. Thus, the January temperature rises at a rate of $1-1.5^{\circ} \mathrm{C}$ over 10 years in most of the European territory of Russia, with the exception of the northeast and the Urals [3]. At the same time, there is no common point of view on the main causes and trends of the dynamics of the modern climate, its consequences for individual components of the natural environment, as well as on the optimization of land use in Siberia [7].

The purpose of our work was to study the effect of relative air humidity on the yield and gross harvest of grain and leguminous crops in the Tyumen region (excluding the autonomous okrugs).

\section{Materials and methods}

Data on the distribution of agricultural land, as well as on agricultural land for 2005-2019 in the Tyumen region (excluding autonomous okrugs) were obtained from the State (national) reports of the Federal Service for State Registration, Cadastre and Cartography [8]. Information on crop area, yield, gross harvest of grain and leguminous crops in the study area for the years 2006-2019 were obtained from the statistical data of Federal Service of State Statistics [9, 10]. Climatic characteristics for 2006-2020 were obtained from the site https://rp5.ru/ [11] from the Tyumen meteorological station. Air temperature, atmospheric pressure, relative humidity, dew point temperature, precipitation, snow depth were analyzed. Quantitative features were subjected to statistical processing using the integrated software package "IBM SPSS Statistics 21" using the following statistical parameters: arithmetic mean, standard deviation, Pearson rank correlation coefficient. Using the Excel program, trend lines were built and the values of the approximation reliability $\left(\mathrm{R}^{2}\right)$ were found.

\section{Results and discussion}

Agricultural production is based on the bioproductive potential of the natural environment. When considering the climatic characteristics of the Tyumen region from the Tyumen meteorological station, the following was revealed (Table 1). For the years under consideration, the average annual temperature was $2.69 \pm 0.22{ }^{\circ} \mathrm{C}$ with an annual gradient of air temperature rise of $0.2^{\circ} \mathrm{C}$. A more intense increase in temperature was observed in the winter period of the year. When considering the relative humidity of the air for the analyzed period, its increase was also established, on average, by $0.1 \%$ annually and amounted to $72.21 \pm 0.26 \%$. At the same time, the greatest gradient of its increase is also observed in the winter period of time $(0.49 \%)$. Thus, when the air temperature in the studied geographic region rises by $1^{\circ} \mathrm{C}$ per year, the relative humidity increases by $0.5 \%$.

Table 1. Climatic characteristics of the study area (average values 2006 - 2020).

\begin{tabular}{|l|c|c|c|c|c|}
\hline \multirow{2}{*}{ Index } & \multicolumn{4}{|c|}{ Seasons } & \multirow{2}{*}{ Year } \\
\cline { 2 - 5 } & Winter & Spring & Summer & Autumn & \\
\hline
\end{tabular}




\begin{tabular}{|l|c|c|c|c|c|}
\hline $\begin{array}{l}\text { Air temperature } \\
\text { / annual } \\
\text { gradient, }{ }^{\circ} \mathrm{C}\end{array}$ & $\frac{-13.84 \pm 0.68}{0.38}$ & $\frac{4.25 \pm 0.39}{0.28}$ & $\frac{17.51 \pm 0.25}{0.11}$ & $\frac{2.47 \pm 0.35}{0.06}$ & $\frac{2.69 \pm 0.22}{0.20}$ \\
\hline $\begin{array}{l}\text { Relative } \\
\text { humidity / } \\
\text { annual gradient, } \\
\%\end{array}$ & $\frac{78.61 \pm 0.54}{0.49}$ & $\frac{61.30 \pm 0.52}{0.20}$ & $\frac{70.55 \pm 0.74}{-0.44}$ & $\frac{78.57 \pm 0.58}{0.16}$ & $\frac{72.21 \pm 0.26}{0.10}$ \\
\hline $\begin{array}{l}\text { Dew point } \\
\text { temperature, }{ }^{\circ} \mathrm{C}\end{array}$ & $-16.91 \pm 0.69$ & $-3.64 \pm 0.36$ & $11.34 \pm 0.15$ & $-1.30 \pm 0.34$ & $-2.55 \pm 0.23$ \\
\hline $\begin{array}{l}\text { Amount of } \\
\text { precipitation, } \\
\text { mm }\end{array}$ & $1.06 \pm 0.06$ & $2.38 \pm 0.16$ & $4.13 \pm 0.27$ & $2.09 \pm 0.14$ & $2.38 \pm 0.09$ \\
\hline $\begin{array}{l}\text { Snow cover } \\
\text { height, cm }\end{array}$ & $30.70 \pm 1.95$ & $33.63 \pm 2.74$ & - & $10.31 \pm 1.10$ & $27.82 \pm 1.67$ \\
\hline
\end{tabular}

According to the Office of the Federal Service for State Registration, Cadastre and Cartography in the Tyumen Region, the land fund within the administrative boundaries of the region as of 01.01 .2020 amounted to 16012.2 thousand hectares. Of these, the share of agricultural land is $24.3 \%$. As can be seen from Table 2, in the Tyumen region without autonomous okrugs for 2005-2019, on average, agricultural land amounted to $4511.35 \pm$ 44.43 thousand hectares.

Table 2. Average values of agricultural land area, distribution of agricultural land, crop area, yield and gross harvest of grain and leguminous crops.

\begin{tabular}{|l|l|l|}
\hline \multicolumn{1}{|c|}{ № } & \multicolumn{1}{|c|}{ Index } & \multicolumn{1}{|c|}{ Value } \\
\hline 1. & Agricultural land, thousand hectares & $4511.35 \pm 44.43$ \\
\hline 2. & Agricultural land - total, thousand hectares & $3384.52 \pm 0.92$ \\
\hline 2.1 & incl. arable land & $1402.89 \pm 13.80$ \\
\hline 3. & Crop area in farms of all categories - total, thousand hectares & $1058.81 \pm 10.37$ \\
\hline 3.1 & incl. grains and legumes & $686.86 \pm 7.32$ \\
\hline 4. & $\begin{array}{l}\text { The yield of grain and leguminous crops (in weight after } \\
\text { processing) in farms of all categories - total, centners per 1 hectare } \\
\text { of harvested area, incl. }\end{array}$ & $20.53 \pm 0.67$ \\
\hline 4.1 & winter wheat & $20.91 \pm 2.14$ \\
\hline 4.2 & spring wheat & $19.59 \pm 0.69$ \\
\hline 4.3 & winter rye & $21.61 \pm 1.14$ \\
\hline 4.4 & oats & $21.28 \pm 0,73$ \\
\hline 4.5 & legumes & $19.45 \pm 0.91$ \\
\hline 5. & $\begin{array}{l}\text { Gross harvest of grain and leguminous crops (in weight after } \\
\text { processing) in farms of all categories - total, thousand tons }\end{array}$ & $1404.48 \pm 49.92$ \\
\hline 5.1 & of which legumes & $55.04 \pm 4.01$ \\
\hline & & \\
\hline
\end{tabular}

The area of agricultural land for the period under consideration was $3384.52 \pm 0.92$ thousand hectares, including arable land $1402.89 \pm 13.80$ thousand hectares. At the same 
time, the crop area in farms of all categories amounted to $1058.81 \pm 10.37$ thousand hectares. The main share of the crop area is occupied by grain and leguminous crops $64.9 \%$ ( $686.86 \pm 7.32$ thousand hectares). It is known that the regions of the Northern Trans-Urals belong to the territories of risky agriculture. It was found that the yield of grain and leguminous crops in farms of all categories was $20.53 \pm 0.67$ centners per hectare of harvested area, and the gross yield of this product was $1404.48 \pm 49.92$ thousand tons. Figure 1 shows a graph of the crop area, yield and gross harvest of grain and leguminous crops from 2006 to 2019 with the construction of a trend line and finding the value of the accuracy of the approximation.

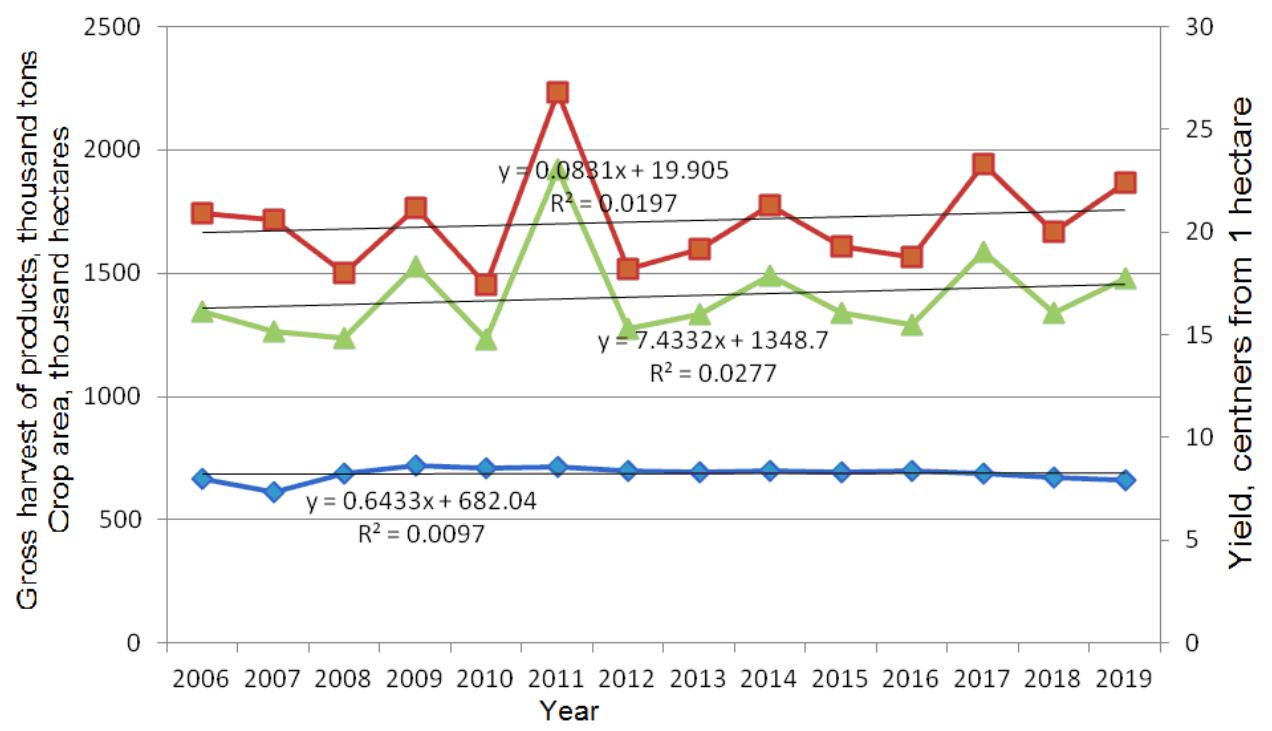

$\checkmark$ Crop area, thousand hectares

Gross harvest of products, thousand tons

Fig. 1. Crop area, yield and gross harvest of grain and leguminous crops from 2006 to 2019.

It was revealed that while maintaining the crop area, the yield $\left(\mathrm{y}=0.0831 \mathrm{x}+19.905 ; \mathrm{R}^{2}\right.$ $=0.0197)$ and gross yield $\left(\mathrm{y}=7.4332 \mathrm{x}+1348.7 ; \mathrm{R}^{2}=0.0277\right)$ of grain and leguminous crops for the period under consideration tend to grow without a clear expression. With a sufficiently high and stable trend of an increase in the average annual relative air humidity, the yield of grain and leguminous crops $(\mathrm{r}=0.63 ; \mathrm{p}=0.015)$, winter and spring wheat $(\mathrm{r}=$ 0.75 at $p=0.002$ and $r=0.63$ at $p=0.015$, respectively), winter rye $(r=0.72 ; p=0.003)$, oats $(r=0.58 ; p=0.029)$ tend to grow. At the same time, the gross harvest of grain and leguminous crops is also growing $(r=0.57 ; \mathrm{p}=0.032)$. When constructing a trend line, it was revealed that the yield of winter wheat $(y=0.9609 x+13.708 ; R 2=0.2515)$ and leguminous crops $(y=0.5637 x+15.222 ; \mathrm{R} 2=0.475)$ grows from year to year. There is also a pronounced tendency to growth and gross harvest of leguminous crops $(\mathrm{y}=2.7534 \mathrm{x}$ $+34.392)$ with a high value of the accuracy of the approximation $(\mathrm{R} 2=0.59)$.

At the same time, the revealed decrease in the relative air humidity in the summer period is also associated with a decrease in the yield of grain and leguminous crops $(\mathrm{r}=$ $0.57 ; \mathrm{p}=0.032)$ and spring wheat $(\mathrm{r}=0.59 ; \mathrm{p}=0.026)$. With a pronounced increase in humidity in winter, the productivity of winter wheat $(\mathrm{r}=0.69 ; \mathrm{p}=0.006)$ and leguminous crops $(r=0.68 ; p=0.007)$ increases. At the same time, the gross harvest of leguminous crops is also growing $(\mathrm{r}=0.68 ; \mathrm{p}=0.007)$.

It is obvious that agriculture is mainly based on the bioresource potential of the natural environment. The climate is the most important factor that determines it. Until recently, 
assessments of the actual state of agriculture, as well as projections, were based on the constancy of the climate. In connection with the observed change in the global climate in the late XX - early XXI century, new, promising approaches to agriculture are needed, since no other sector is so sensitive to the effects of climate. The above analysis showed that for 2006-2019, the crop area, yield and gross yield of grain and leguminous crops for the period under consideration tend to grow without obvious expression. Consideration of climatic characteristics for 2006-2020 showed that the average annual temperature and relative humidity of the air are steadily increasing. At the same time, the increase in air temperature by $1{ }^{\circ} \mathrm{C}$ per year, the relative humidity increases by $0.5 \%$. Thus, the climate in the area under consideration has become milder, therefore, the natural and ecological characteristics are favorable for the active economic use of the agricultural landscape of the Northern Trans-Urals for the cultivation of grain and leguminous crops. This dictates the need to take measures aimed at adapting agriculture to new conditions and focused on environmentally friendly land use technologies.

\section{Conclusions}

The modern climate dictates new living conditions. In this regard, its changes represent a complex interdisciplinary problem. The study of climatic characteristics in the Tyumen region (without the autonomous okrugs) showed that for 2006-2020 the average annual temperature and relative humidity are increasing. At the same time, it was found that the relative humidity of the air directly affects the yield and gross harvest of grain and leguminous crops in the Tyumen region (without the autonomous okrugs). An increase in humidity and air temperature in the area under consideration favors active economic use of the agricultural landscape of the Northern Trans-Urals. This dictates the need to take measures aimed at adapting agriculture to new conditions and focused on environmentally friendly land use technologies. Work in this direction will continue taking into account the influence of soil properties, adaptation of agricultural technologies to the conditions of global climate change.

\section{Acknowledgments}

The research work was carried out according to the state assignment for 2021-2030 Spatiotemporal phenomena and processes occurring in the waters of the land of Siberia in the modern technogenesis and climate change (Priority direction 1.5.11. Program 1.5.11.1).

\section{References}

1. V.V. Ivanov, V.A. Alekseev, T.A. Alekseeva, N.V. Koldunov, I.A. Repina, A.V. Smirnov, Exploration of the Earth from Space, 4, 50-65 (2013)

2. M.M. Shatz, Yu.B. Skachkov, Climate and Nature, 2 (19), 27-37 (2016) http://climate2008.igce.ru/v2008/htm/index00.htm

3. Report on climate risks in the Russian Federation (St. Petersburg, 2017)

4. V. M. Kattsov, B. N. Porfiriev, Arctic: ecology and economics, 2 (6), 66-79 (2012)

5. Ju-Young Shin, Kyu Rang Kim, Jinwon Kim, Seungbum Kim, Int J Climatol, 1-21 (2021) https://doi.org/10.1002/joc.7068

6. A. G. Paptsov, N. A. Shelamova, Global Food Security in the Context of Climate Change (Moscow, RAS, 2018) 
7. https://rosreestr.gov.ru/site/activity/gosudarstvennoe-upravlenie-v-sfere-ispolzovaniyai-okhrany-zemel/gosudarstvennyy-natsionalnyy-doklad-o-sostoyanii-i-ispolzovaniizemel-rossiyskoy-federatsii/

8. Statistical Yearbook Tyumen Region (except for the Khanty-Mansiysk Autonomous Okrug - Yugra and the Yamalo-Nenets Autonomous Okrug) in 2 parts. Part I (II) (1990-2016) (Tyumen, Office of the Federal State Statistics Service for the Tyumen Region, Khanty-Mansiysk Autonomous Okrug - Yugra and Yamalo-Nenets Autonomous Okrug, 2020)

9. Statistical Yearbook Tyumen Region (except for the Khanty-Mansiysk Autonomous Okrug - Yugra and the Yamalo-Nenets Autonomous Okrug) in 2 parts. Part II (20172019) (Tyumen, Office of the Federal State Statistics Service for Tyumen Region, Khanty-Mansi Autonomous Okrug - Yugra and Yamalo-Nenets Autonomous Okrug, 2020)

10. https://rp5.ru/ 